ORIGINAL ARTICLE

\title{
EFFECTS OF METHANOL EXTRACT AND N-HEXANE EXTRACT OF PAPAYA LEAVES (CARICA PAPAYA L) ON TOTAL AND DIFFERENTIAL WHITE BLOOD CELL COUNTS IN MALE WISTAR RATS AFTER CARRAGEENAN INDUCTION
}

\author{
Okto P. E. Marpaung ${ }^{1 *}$, Datten Bangun ${ }^{2}$, Syafruddin Ilyas ${ }^{2}$ \\ ${ }^{1}$ Faculty of Medicine, Universitas HKBP Nommensen Medan, Indonesia \\ ${ }^{2}$ Magister of Biomedicine, Faculty of Medicine, University of Sumatera Utara, Indonesia \\ *Corresponding author: oktomarpaung83doc@gmail.com
}

\begin{abstract}
As one of the countries producing medicinal plants, Indonesia has the potential to develop medicinal plants in the future. The anti-inflammatory effects of methanol and n-hexane extract from papaya leaves were seen in this study using a pretest-posttest control group design using 36 male adult Wistar rats divided into 6 groups. All rats received 1 week acclimatization, then blood specimens were taken from the tail, after which they were treated, and intraplantar injections were carried out with $1 \%$ carrageenan solution as much as $0.1 \mathrm{ml}$. Then retrieval of blood specimens from rats' tails at 3 hours and 6 hours afterwards. Then an examination of the number and type of leukocytes was performed on all blood specimens obtained. It was found that the number of male Wistar rat leukocytes after getting methanol extract of papaya leaves was lower but not significant ( $p>0.05$ ) compared to those who did not. The increase in the number of leukocytes cannot be restrained significantly by the administration of $n$-hexane extract. It was found that changes in leukocyte counts in acute inflammatory conditions with the administration of methanol extract and n-hexane extract of Papaya Leaves. The increase number of neutrophils and monocytes in acute inflammatory conditions can be significantly suppressed by the administration of methanol extract of papaya leaves.
\end{abstract}

Key words: inflammation, carrageenan, papaya, Carica papaya 1

\section{INTRODUCTION}

At present Indonesia is one of the potential producing plants, where the most widely used natural products are medicinal plants and have been used for a long time. Although modern medicine is growing rapidly, the potential of medicinal plants is still high because it can be obtained without a doctor's prescription, can be mixed alone, and medicinal plants can be planted by the wearer themselves. ${ }^{1}$

Vegetables are one of the foods contained in the daily diet. Nowadays vegetable consumption in Indonesia tends to increase along with the growing awareness of the importance of vegetables for human health. As a 
tropical country, Indonesia has abundant natural resources for vegetables. According to the records, there are 370 types of vegetableproducing plants that are regularly utilized by the community. ${ }^{2}$

In a study, it was found that papaya leaf extract had an antiinflammatory effect in mice infected by Salmonella typhi and Staphylococcus aureus. This study uses hematological parameters to see the effect of papaya leaf extract on the infection (Leukocytes, hemoglobins, hematocrit, neutrophils, lymphocytes, monocytes and lymphocytes). ${ }^{3}$

Various attempts have been made to find new alternative treatments as an anti-inflammatory. Several studies have shown that administration of ethanol extract of papaya leaves can act as an anti-inflammatory. ${ }^{4}$ However, it is not known which compounds have a strong effect on the anti-inflammatory process. Based on this, it is necessary to conduct research to determine the antiinflammatory effects of methanol extract and n-hexane of papaya leaves.

\section{METHODS}

The research was an experimental study using male Wistar rats. The research methodology included preparing samples, making methanol extract and n-hexane by macerating papaya leaves, testing antiinflammatory effects. This research was carried out at the Pharmacy Pharmacology laboratory at the Universitas Sumatera Utara, the Natural Chemistry Organic Laboratory FMIPA Universitas Sumatera Utara and the Biology Laboratory of the Faculty of Mathematics and Natural Sciences, Universitas Sumatera Utara. This study used male Wistar rats (Rattus norvegicus) obtained from USU's FMIPA with a body weight of 150-250 grams, 36 weeks old and 36 divided into 6 groups.

On the day of testing, each animal is weighed. Before the treatment, blood was taken from the base of the rat's tail, then an examination of the number of leukocytes with a Haemocytometer and examination of leukocyte counts. Then in each group (P0-P5) treatment is given as in the table below.

\section{Table 1. Experiment Animal in} Effects of Acute Inflammatory Treatment

\begin{tabular}{lllc}
\hline No Group & Treatment & Amount \\
\hline 1 & $\begin{array}{l}\text { Group } \\
\text { P0 }\end{array}$ & Saline (per oral) & 6 \\
\hline 2 & $\begin{array}{l}\text { Group } \\
\text { P1 }\end{array}$ & $\begin{array}{l}\text { Indomethacin 10 } \\
\text { mg/kgBB (per oral) }\end{array}$ & 6 \\
\hline 3 & $\begin{array}{l}\text { Group } \\
\text { P2 }\end{array}$ & $\begin{array}{l}\text { The methanol extract of } \\
\text { papaya leaves dosage I } \\
(250 \text { mg/kg) }\end{array}$ & 6 \\
\hline 4 & $\begin{array}{l}\text { Group } \\
\text { P3 }\end{array}$ & $\begin{array}{l}\text { The methanol extract of } \\
\text { papaya leaves dosage } \\
\text { II }(500 \mathrm{mg} / \mathrm{kg})\end{array}$ & 6 \\
\hline 5 & $\begin{array}{l}\text { Group } \\
\text { P4 }\end{array}$ & $\begin{array}{l}\text { Extract n-hexane } \\
\text { papaya leaves dosage I } \\
(250 \text { mg/kg) }\end{array}$ & 6 \\
\hline 6 & $\begin{array}{l}\text { Group } \\
\text { P5 }\end{array}$ & $\begin{array}{l}\text { Extract } \mathrm{n}-\mathrm{h} \text { pexane } \\
\text { papaya leaves dosage II } \\
(500 \mathrm{mg} / \mathrm{kg})\end{array}$ & 6 \\
\hline
\end{tabular}

One hour later each rat's foot was injected intraplantar by a subcutaneous method with $0.1 \mathrm{ml}$ of $1 \%$ subcutaneous carrageenan solution. After 3 hours and six hours of carrageenan injection taken again from the base of the rat's tail, then carried out an examination of the number of leukocytes with Haemocytometer and examination of leukocyte count. 


\section{RESULTS}

Observation data of the antiinflammatory effect of methanol extract and n-hexane of papaya leaves were analyzed by complete randomized design ANOVA. From each male Wistar mouse, blood samples were taken 3 times, namely when: before male Wistar rats are given carrageenan, three hours after male Wistar mice are injected with carrageenan, and six hours after male Wistar rats were injected with carrageenan

From these three types of data, for each group, a statistical analysis was performed using Repeated ANOVA if the data had a normal distribution, but if the data distribution was not normal, the Friedman Statistical Test was carried out, and if differences were found followed by the Post Hoc test, Wilcoxon.

To test for significant differences between the test groups, the Student Newman Keuls test (SNK test) was used. Data is processed with SPSS 15.0 and tested by ANOVA test, where the statistical test results will be significant if $\alpha \leq 0.05$.

From the qualitative test conducted, it appears that papaya leaves contain alkaloids, flavonoids, saponins, and tannins. This flavonoid compound is thought to cause an anti-inflammatory effect.

Table 2. Examination results of papaya leave contents

\begin{tabular}{cccccc}
\hline \multirow{2}{*}{ Zat } & \multicolumn{2}{c}{ Alka- } & Flavo-Glyco- Sapo- & Tan- \\
& loids & noid & side & nin & nin \\
\hline $\begin{array}{c}\text { Positive/ } \\
\text { Negative }\end{array}$ & + & + & - & + & + \\
\hline
\end{tabular}

From the data obtained, it appears that leukocyte counts increase significantly with stimulation by carrageenan (group P0).

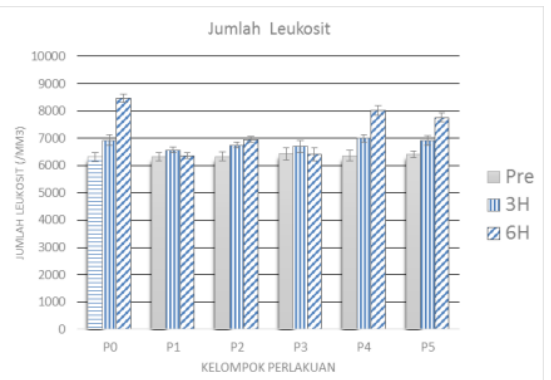

Figure 1. Comparison of leukocyte counts before, 3 hours and 6 hours after carrageenan injection

(Pre $=$ before, $3 \mathrm{H}=3$ hours after injection, $6 \mathrm{H}=$ 6 hours after injection)

From the picture above, it can be seen that the increase in the number of leukocytes is evident at the 3rd and 6th hours in the P0, P2, P4 and P5 groups (p $<0.05)$. In groups $\mathrm{P} 1$ and $\mathrm{P} 3$ there were no significant differences ( $p>0.05$ ) in the number of leukocytes at the 3 hours and 6 hours after administration of carrageenan.

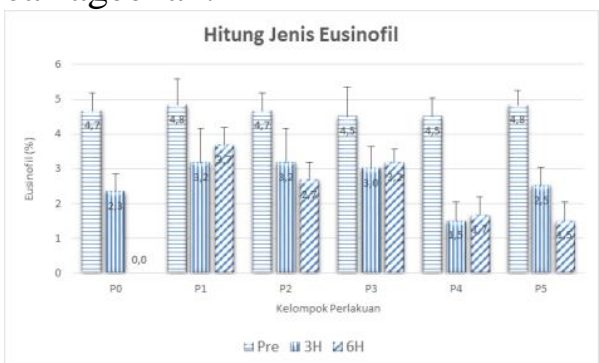

Figure 2. Comparison of eosinophil counts before, 3 hours and 6 hours after carrageenan injection

(Pre $=$ before, $3 \mathrm{H}=3$ hours after injection, $6 \mathrm{H}=$ 6 hours after injection)

From the picture above it can be seen that there was a significant decrease in the number of eosinophils counts in the P0 group ( $\mathrm{p}<0.05)$ at 3 hours and 6 hours after the carrageenan administration of the eosinophil count before carrageenan administration which was a negative control. 
Table 3. Leukocyte and White Blood Cells count in Male Wistar rats before Carrageenan injection

\begin{tabular}{|c|c|c|c|c|c|c|c|c|}
\hline \multirow{2}{*}{$\begin{array}{l}\text { Treatment } \\
\text { Group }\end{array}$} & \multirow{2}{*}{$\mathbf{n}$} & \multirow{2}{*}{ Time } & \multicolumn{5}{|c|}{ Leukocyte differential count (\%) } & \multirow{2}{*}{$\begin{array}{c}\text { Leukocyte } \\
\text { count }\left(/ \mathbf{m m}^{3}\right)\end{array}$} \\
\hline & & & Eosinophil & Basophil & Neutrophil & Lymphocyte & Monocyte & \\
\hline \multirow{3}{*}{ P0 } & \multirow{3}{*}{6} & Pre & $4,7 \pm 0,52$ & $1,8 \pm 0,41$ & $19,3 \pm 1,21$ & $69,8 \pm 0,75$ & $4,3 \pm 1,03$ & $6316,7 \pm 160,21$ \\
\hline & & $\begin{array}{c}3 \\
\text { hours }\end{array}$ & $2,3 \pm 0,52$ & $1,3 \pm 0,82$ & $35,2 \pm 1,17$ & $55,5 \pm 1,38$ & $5,7 \pm 0,52$ & $6933,3 \pm 206,56$ \\
\hline & & $\begin{array}{c}6 \\
\text { hours } \\
\end{array}$ & $0,0 \pm 0,00$ & $0,0 \pm 0,00$ & $51,2 \pm 1,33$ & $42,0 \pm 1,41$ & $6,8 \pm 0,8$ & $8466,7 \pm 163,3$ \\
\hline \multirow{3}{*}{ P1 } & \multirow{3}{*}{6} & Pre & $4,8 \pm 0,75$ & $2,3 \pm 0,52$ & $19,8 \pm 1,17$ & $67,1 \pm 2,07$ & $5,3 \pm 1,63$ & $6316,7 \pm 147,20$ \\
\hline & & $\begin{array}{c}3 \\
\text { hours }\end{array}$ & $3,2 \pm 0,98$ & $1,8 \pm 0,41$ & $27,0 \pm 1,41$ & $64,3 \pm 0,82$ & $3,7 \pm 0,52$ & $6566,7 \pm 103,28$ \\
\hline & & $\begin{array}{c}6 \\
\text { hours }\end{array}$ & $3,7^{\prime} \pm 0,52$ & $1,8 \pm 0,41$ & $22,5 \pm 1,52$ & $68,8 \pm 2,04$ & $3,2 \pm 0,4$ & $6366,7 \pm 103,28$ \\
\hline \multirow{3}{*}{$\mathbf{P 2}$} & \multirow{3}{*}{6} & Pre & $4,7 \pm 0,52$ & $2,0 \pm 0,63$ & $19,2 \pm 1,17$ & $69,8 \pm 1,47$ & $4,3 \pm 1,21$ & $6333,3 \pm 163,30$ \\
\hline & & $\begin{array}{c}3 \\
\text { hours }\end{array}$ & $3,2 \pm 0,98$ & $2,0 \pm 0,00$ & $24,7 \pm 1,63$ & $65,5 \pm 1,05$ & $4,7 \pm 1,03$ & $6750 \pm 104,88$ \\
\hline & & $\begin{array}{c}6 \\
\text { hours } \\
\end{array}$ & $2,7 \pm 0,52$ & $1,2 \pm 0,41$ & $21,5 \pm 1,05$ & $70,7 \pm 1,51$ & $4,0 \pm 0,9$ & $6950,0 \pm 104,88$ \\
\hline \multirow{3}{*}{ P3 } & \multirow{3}{*}{6} & Pre & $4,5 \pm 0,84$ & $2,0 \pm 0,63$ & $18,7 \pm 1,37$ & $69,8 \pm 1,72$ & $5,0 \pm 1,26$ & $6433,3 \pm 216,02$ \\
\hline & & $\begin{array}{c}3 \\
\text { hours }\end{array}$ & $3,0 \pm 0,63$ & $2,0 \pm 0,00$ & $24,5 \pm 0,55$ & $67,8 \pm 0,75$ & $2,7 \pm 0,82$ & $6700 \pm 228,04$ \\
\hline & & $\begin{array}{c}6 \\
\text { hours }\end{array}$ & $3,2 \pm 0,41$ & $2,0 \pm 0,00$ & $16,8 \pm 1,33$ & $75,2 \pm 1,94$ & $, 2,8 \pm 0,8$ & $6416,7 \pm 231,66$ \\
\hline \multirow{3}{*}{ P4 } & \multirow{3}{*}{6} & Pre & $4,5 \pm 0,55$ & $2,0 \pm 0,63$ & $20,2 \pm 1,72$ & $69,2 \pm 1,33$ & $4,2 \pm 0,98$ & $6366,7 \pm 206,56$ \\
\hline & & $\begin{array}{c}3 \\
\text { hours }\end{array}$ & $1,5 \pm 0,55$ & $0,7 \pm 0,52$ & $33,3 \pm 2,16$ & $59,2 \pm 2,14$ & $5,3 \pm 0,82$ & $7000 \pm 141,42$ \\
\hline & & $\begin{array}{c}6 \\
\text { hours } \\
\end{array}$ & $1,7 \pm 0,52$ & $0,0 \pm 0,00$ & $43,2 \pm 0,98$ & $48,3 \pm 1,21$ & $6,8 \pm 0,8$ & $8016,7 \pm 172,34$ \\
\hline \multirow{3}{*}{ P5 } & \multirow{3}{*}{6} & Pre & $4,8 \pm 0,41$ & $1,5 \pm 0,55$ & $18,8 \pm 1,47$ & $70,0 \pm 1,26$ & $4,8 \pm 0,75$ & $6416,7 \pm 116,90$ \\
\hline & & $\begin{array}{c}3 \mathrm{j} \\
\text { hours }\end{array}$ & $2,5 \pm 0,55$ & $0,8 \pm 0,41$ & $28,8 \pm 0,98$ & $62,5 \pm 1,87$ & $5,3 \pm 1,21$ & $6916,7 \pm 172,24$ \\
\hline & & $\begin{array}{c}6 \\
\text { hours }\end{array}$ & $1,5 \pm 0,55$ & $0,8 \pm 0,41$ & $44,5 \pm 1,05$ & $48,5 \pm 0,84$ & $4,7 \pm 0,5$ & $7766,7 \pm 163,30$ \\
\hline
\end{tabular}

In groups P1, P2, P4, P5 ( $\mathrm{p}<0.05)$ there was a significant difference between eosinophil counts before and after carrageenan administration. In group P1, $\mathrm{P} 2, \mathrm{P} 4$ there was no significant difference (p>0.05) between the count of eosinophil type 3 hours and 6 hours after carrageenan administration

In the P3 group, there was no significant difference ( $p>0.05$ ) between the eosinophil count before and after carrageenan administration.

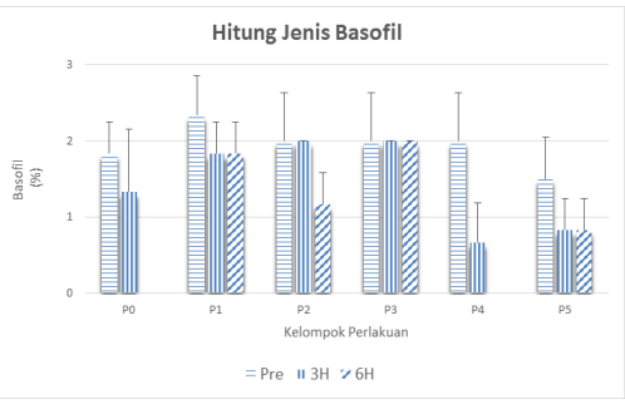

Figure 3. Comparison of Basophil count before, 3 hours after and 6 hours after carrageenan injection

(Pre $=$ before, $3 \mathrm{H}=3$ hours after injection, $6 \mathrm{H}=6$ hours after injection) 
From the picture above it can be seen that in groups P0, P4, P5 there was a significant decrease $(p<0.05)$ from the number of basophil counts before and after carrageenan administration. In group P1, P2, P3 there was no significant difference (p> 0.05) from the number of basophil counts before and after carrageenan administration.

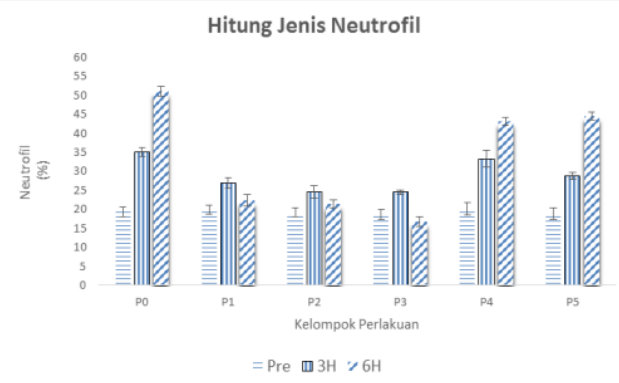

Figure 4. Comparison of Neutrophil counts before, 3 hours after and 6 hours after carrageenan injection

(Pre $=$ before, $3 \mathrm{H}=3$ hours after injection, $6 \mathrm{H}=6$ hours after injection)

From the picture above it can be seen that in groups $\mathrm{P} 0, \mathrm{P} 1, \mathrm{P} 2, \mathrm{P} 3, \mathrm{P} 4$, and $\mathrm{P} 5$ there were significant differences ( $\mathrm{p}$ $<0.05)$ between the number of neutrophil counts before and after carrageenan administration.

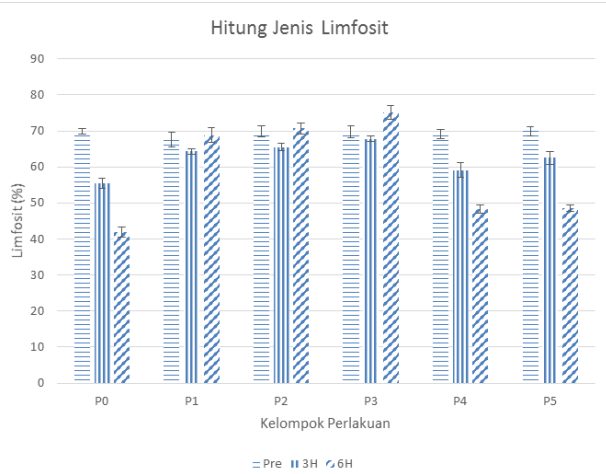

Figure 5. Comparison of types of lymphocytes before, 3 hours and 6 hours after carrageenan injection

(Pre $=$ before, $3 \mathrm{H}=3$ hours after injection, $6 \mathrm{H}=6$ hours after injection)

From the picture, it can be seen that there are significant differences in the types of lymphocytes in groups $\mathrm{P} 0, \mathrm{P} 1, \mathrm{P} 2$, P3, P4 and P5 ( $p<0.05)$ before and after carrageenan.

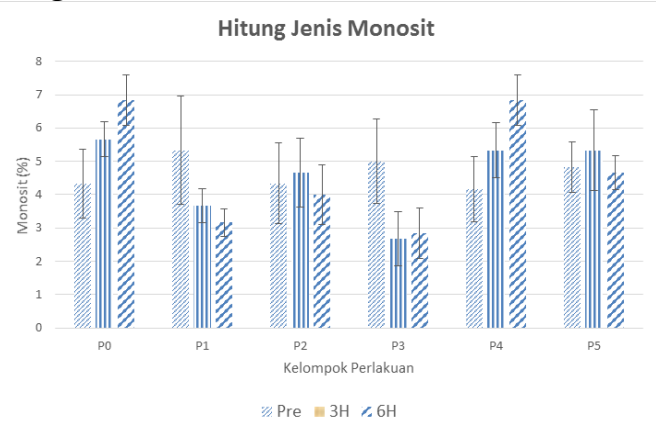

Figure 6. Comparison of Monocytes counts before, 3 hours after and 6 hours after carrageenan injection

(Pre $=$ before, $3 \mathrm{H}=3$ hours after injection, $6 \mathrm{H}=6$ hours after injection)

From the picture above it can be seen that there is a significant increase in the number of monocyte counts $(\mathrm{p}<0.05)$ in groups $\mathrm{P} 0, \mathrm{P} 3, \mathrm{P} 4$, and $\mathrm{P} 4$. In group $\mathrm{P} 1$, $\mathrm{P} 2$, P5, there was no difference in monocyte count before and after carrageenan administration ( $p>0.05$ )

\section{DISCUSSION}

The administration of indomethacin and methanol extract of papaya leaves at a dose of $500 \mathrm{mg} / \mathrm{kg}$ can withstand an increase in leukocyte counts so that after the injection of carrageenan the number of leukocytes is not significantly different, so it can be concluded that the doses of papaya leaves with the same effect compared to indomethacin. The n-hexane extract from papaya leaves could not resist the increase in the number of leukocytes after carrageenan administration at both available doses of the extract. The flavonoid content in papaya leaves is one component that has an anti-inflammatory effect that is expected to affect the amount and count of leukocyte types. The nhexane extract from papaya leaves in this study did not affect the number of leukocytes, one of which could be caused by the low content of flavonoids (polar) in 
non-polar n-hexane extract. ${ }^{5,6}$ This is in line with the research previously conducted by Nahed. ${ }^{7}$

In the eosinophil count, there was a significant decrease in the negative control group until eosinophils were not obtained in the count type. This occurs because of the emphasis caused by increased levels of Interleukin-1 (IL-1). In groups P1, P2, P4 there was also a significant decrease equal to $\mathrm{P} 0$. In the administration of methanol extract of papaya leaves at a dose of 500 $\mathrm{mg} / \mathrm{kg}$, there was no significant difference between eosinophil count before and after carrageenan administration, this might be caused by suppression of IL-1 by methanol extract from papaya leaves.

In basophil count in group P0 (which is negative control), P4, and P5 there was a significant decrease in the number of basophils before and after carrageenan administration. The administration of indomethacin and methanol extract from papaya leaves caused no significant difference from basophil count before and after carrageenan administration. This is also caused by suppression of $\mathrm{IL}-1$ by methanol extract from papaya leaves.

In the neutrophil count in groups $\mathrm{P} 0$, P4 and P5 there was a significant increase in the number of neutrophil counts. In the group that received indomethacin and methanol extract from papaya leaves, there was a $52 \%$ reduction in the count of neutrophils at the 6th hour, but the decline was not significant.

In the lymphocyte count in all groups, there were significant differences between before and after carrageenan administration.

In monocyte counts there is an increase in the number of monocyte counts that are significant in groups P0, P3, and $\mathrm{P} 4$, this is in line with the acute inflammatory process that occurs. In group $\mathrm{P} 1$, P2, P5 there were no significant differences before and after carrageenan administration, this indicated that indomethacin and methanol extract and nhexane from papaya leaves suppressed the increase in the number of monocytes that occur in the acute inflammatory process.

\section{CONCLUSIONS}

Based on the results and discussion of research on the effects of methanol extract and $n$-hexane extract of papaya leaves (Carica papaya 1) on the number and count of leukocytes in male Wistar rats after carrageenan induction, it can be concluded that the number of male Wistar leukocytes which received methanol extract of papaya leaves was lower but not significant $(p>0.05)$ compared to those who did not get the methanol extract of papaya leaves. The n-hexane extract of papaya leaves cannot resist the increase in leukocyte counts significantly.

The methanol extract and n-hexane of papaya leaves cause changes in leukocyte counts in acute inflammatory conditions. The methanol extract of papaya leaves was significantly able to withstand an increase in the number of neutrophils and monocytes in acute inflammatory conditions.

In acute inflammation induced by carrageenan, there was a marked decrease in the number of eosinophils caused by eosinophil suppression by increased levels of Interleukin.

\section{ACKNOWLEDGEMENTS}

The author express gratitude to Purba Marpaung, Berlian Manurung, Ilham Hariaji and Gohan Situmeang that are very supportive throughout the process of finishing article.

\section{REFERENCE}

1. Djauhariya E, Hernani. Gulma Berkhasiat Obat. Jakarta: Penebar Swadaya; 2004:74-75. 
2. Mangoting D, Irawan I, Abdullah S. Tanaman Lalap Berkhasiat Obat. Jakarta: Penebar Swadaya; 2005.

3. Oladunmoye M, Osho I. Antiinflammatory Activity of Ethanolic Leaf Extract from Carica papaya in Rats Orogastrically Dosed with Salmonella typhi and Staphylococcus aureus. Journal of Plant Sciences. 2007;2(4):447-452. doi:10.3923/jps.2007.447.452

4. Owoyele B, Adebukola O, Funmilayo A, Soladoye A. Anti-inflammatory activities of ethanolic extract of Carica papaya

leaves. Inflammopharmacology. 2008;16(4):168-173. doi:10.1007/s10787-008-7008-0

5. Imaga. Analyses of antisickling potency of Carica papaya dried leaf extract and fractions. Journal of Pharmacognosy and Phytotherapy. 2010; 2(7): 97-102.

6. Lenny S. Senyawa flavonoida, fenil propanoid, dan alkaloid. Library.usu.ac.id. http://library.usu.ac.id/download/fmip a/06003489.pdf. Published 2006. 